\title{
Integrated territorial investments: challenges and opportunities - case study of Romania
}

\author{
F. Gaman ${ }^{1}$, O. Luca ${ }^{1}$, S. I. Burduja ${ }^{2}$, M. Aldea ${ }^{1}$, C. Iacoboaea ${ }^{1}$, \\ F. Petrescu ${ }^{1} \&$ M. Șercăianu ${ }^{1}$ \\ ${ }^{I}$ Department of Urban Engineering and Regional Development, \\ Technical University of Civil Engineering Bucharest, Romania \\ ${ }^{2}$ C.A.E.S.A.R. Foundation, Romania
}

\begin{abstract}
In order to facilitate the delivery of integrated development strategies, the European Commission has identified two separate tools: Community-Led Local Development (CLLD) and Integrated territorial investment (ITI). ITI is an instrument, which has been developed for the delivery of funding in geographical areas with particular territorial features, ranging from specific urban neighbourhoods with multiple deprivations to the urban, metropolitan, urban-rural, sub-regional, and inter-regional levels. The Romanian Partnership Agreement for the 2014-2020 programming period highlighted that Romania will prioritize the implementation of ITI in the Danube Delta Biosphere. In this document, unfortunately, growth poles (GPs) are not specifically considered for ITI implementation at this time, though this new instrument could bring significant benefits to Romania's growth engines. The present paper aims to explore the possibilities of ITI application in Romania's GPs, building on the existing concept of integrated urban development, which is already functional in Romania. The exploration will take into account the manifold problems that have appeared in Romania during the 2007-2013 implementation period, including significant criteria that should be developed in selecting ITI areas: the record of contracting rates and absorption rates as potential options. At the same time, the paper aims to introduce an innovative matrix for prioritization of actions within an ITI, in order to maximize their impact. A case study will be developed for Bucharest - as potential area for ITI implementation - emphasizing the role of climate change indicators within the proposed matrix.

Keywords: integrated urban development, integrated territorial investments, prioritization, climate change indicators.
\end{abstract}




\section{Introduction}

In setting out the delivery framework for the 2014-2020 Structural Funds, the European Commission (EC) has recognized the importance of cities by introducing a "place based" approach to the delivery of EU funds. The proposed delivery mechanisms recognize that while governments and regional administrations will want to set regional policy, the implementation of these policies at a local level needs to reflect local circumstances and challenges in an integrated way to best address relevant challenges.

In order to facilitate the delivery of integrated development strategies, the EC has identified two separate tools. One of them is the Community-Led Local Development (CLLD) instrument, which is deemed appropriate for urban areas with a population of less than 150,000 people, building on the LEADER program that was applied in rural areas in the 2007-2013 programming period.

The second tool, the integrated territorial investment (ITI) instrument, has been developed for the delivery of funding in geographical areas with particular territorial features, ranging from specific urban neighbourhoods with multiple deprivations to the urban, metropolitan, urban-rural, sub-regional, and interregional levels.

It is envisaged that these instruments would draw down especially ERDF and ESF funds to support the delivery of projects as part of an Integrated Development Strategy for a defined geographical area. Furthermore, the EC has made provisions to allow an ITI to also be supported by the European Agricultural Fund for Rural Development (EAFRD) and the European Fisheries Fund (EFF).

\section{Key elements of ITI}

ITI is "a territorial delivery mechanism that enables the implementation of a territorial strategy in an integrated manner while drawing funds from at least two different priority axes in the same or different programs" [1].

Using this instrument, associations of territorial self-government units of functional areas will be able to implement integrated projects, and most of all, combine activities financed from different European funds as shown in Figure 1.

ITI will be applied in Romania following the principles of integrated urban development - a concept with a long history generally, although in Romania becoming more popular only recently, catalysed by the country's accession to the EU and by increased exposure to the practice and policies of urban development in the European space. The concept was introduced as structural funds were redirected to cities based on Integrated Urban Development Plans (IUDPs) and as part of a growing emphasis of the EU's cohesion policy on cities. Soto et al. [2] identify six possible types of it presented in Table 1, applied for settlements in Romania. 


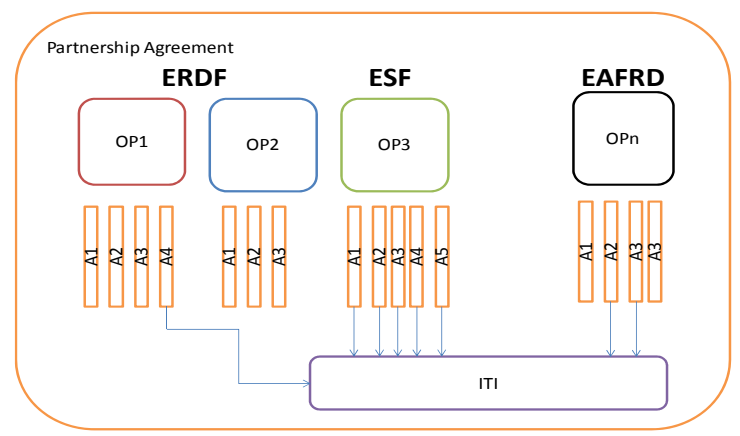

Figure 1: ITI is a tool for integrated development strategies combining funds from different programs/axes.

\section{Table 1: $\quad$ Possible types of ITI.}

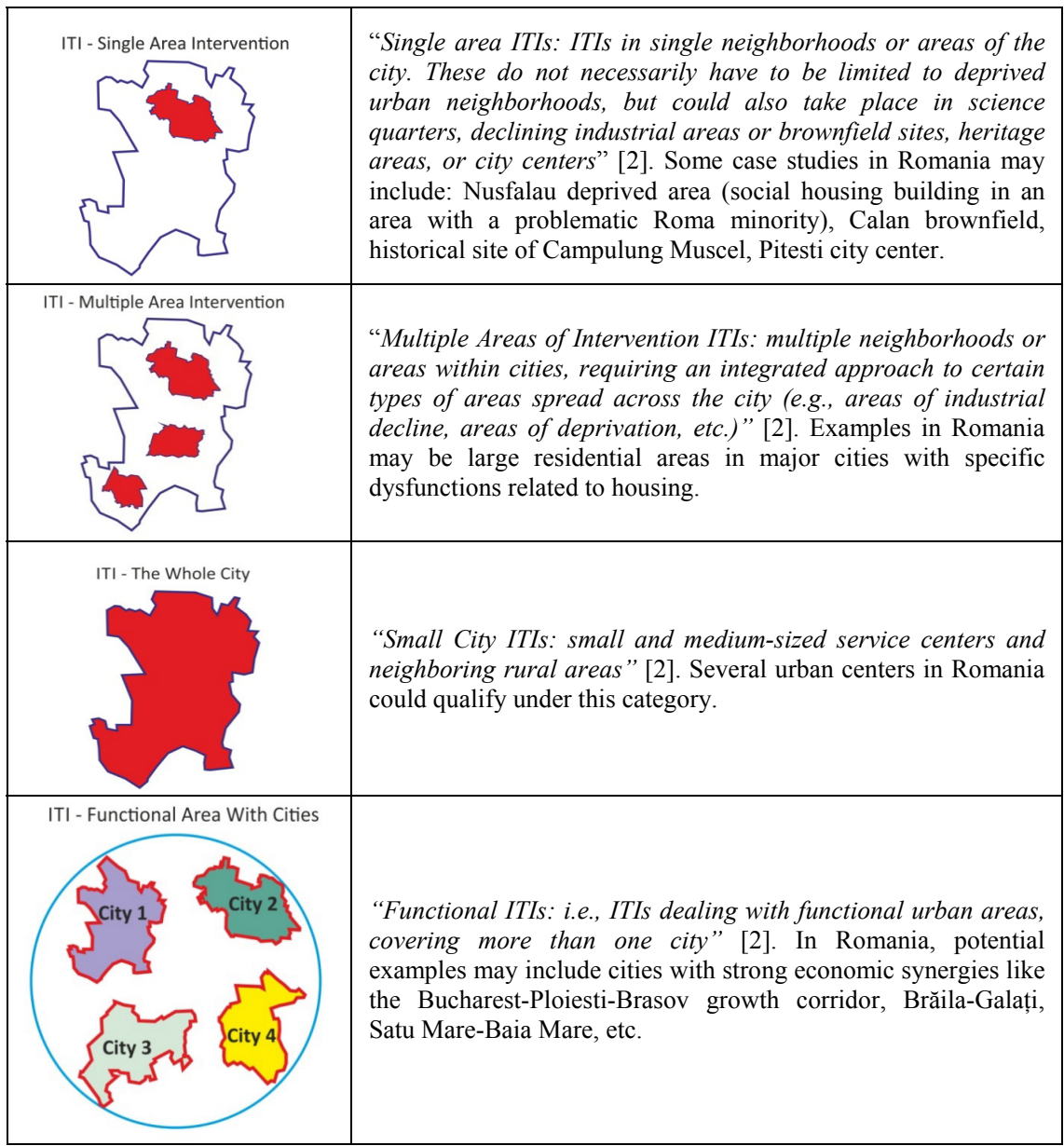


Table 1: Continued.

"Rural-Urban Linkages ITIs: ITIs dealing with certain key
urban-rural linkages" (e.g., transport and business corridors
between urban and rural areas, cross-border areas, etc.) [2].
Romanian GPs, particularly those with a high growth potential,
as suggested by recent trends (e.g., Cluj and Timișoara) would
be fine examples of this ITI type.

\section{Romanian case study: IUDPs implementation and recommendations for ITI}

In recent years, a new planning instrument - the IUDP - was used in Romania for GPs, Urban Development Poles (UDPs), and Urban Centres (UCs), as required to apply for funding available through Axis 1 for urban development under the 2007-2013 Regional Operational Program (ROP). This plan includes the same chapters as the City Strategy, but it also goes beyond the city's administrative boundaries, typically covering the metropolitan areas (defined, according to the legislation, as the 30-kilometer buffer around the main urban centre). IUDPs include a list of projects, based on an estimation of the predetermined ROP allocation. In practice, however, most proposed projects and interventions have concentrated on the urban centre at the core of a metropolitan area, which has created tensions among local authorities in neighbouring localities. Often times, these stakeholders did not see a direct benefit from joining a particular metropolitan area given that they were not able to attract more funding and, even when they were successful in financing certain interventions, these were limited to social centers or other projects with little potential for economic development.

While the IUDPs have clear gaps, they were the first integrated development exercise that Romania completed during the previous programming period. Especially for GPs, however, they may constitute a solid foundation for ITI implementation [3].

Romania will prioritize the implementation of ITI in the Danube Delta Biosphere [4]. GPs are not specifically considered for ITI implementation at this time, though this new instrument could bring significant benefits to Romania's growth engines. Moreover, the draft budgetary allocation as of July 2014 raises 
serious concerns: the Danube Delta region is to receive over EUR 1 billion, including over 300 million for the Tulcea and Sulina municipalities, while much larger cities (GPs) with a high growth potential would only be allocated around EUR 40 million for 2014-2020. If Romania is to achieve inclusive and sustainable development, the next seven years are truly critical and resources should be prioritized based on each area's potential to generate growth.

\subsection{Key lessons learned and implications for Romania's ITIs based on 2007-2013 IUDPs}

There are three key elements of an ITI:

i) an integrated development strategy for a designated territory including

ii) a package of actions to be implemented with

iii) strong governance arrangements.

3.1.1 The 'designated territory' could be a specific geographic area within a region, for example, a Growth Pole (Craiova), a Development Pole (Sibiu), a resort (Băile Herculane), or areas of deprivation within these cities (Ferentari in Bucharest), or it could focus on cross-border city cooperation (Giurgiu-Ruse).

The designated territory approach in the previous programming period targeted GPs, which had to elaborate IUDPs for their metropolitan area.

3.1.2 The 'designated territory' should benefit from an integrated territorial development strategy that addresses the development needs of the targeted area.

Romanian GPs have made important steps toward an integrated development approach through IUDPs, which may be considered potential precursors to the successful development and implementation of an ITI.

3.1.3 A package of actions (an investment plan) to be implemented, which should contribute to the objectives of the territorial strategy (e.g., tackling urban deprivation, supporting SMEs, improving the environment, promoting energy efficiency, etc.). An important issue is to draw the funds from at least two different priority axes or programs and ensure that these funds are used in an integrated manner [5].

The IUDPs have action plans which, even if include projects to be financed by other Operational Programs or axes in the same OP, do not have a coordination component for all interventions, but only for projects financed by the ROP under axis 1 (i.e., GPs, Urban Development Poles, and Urban Centers). Often times, the action plan does not include all projects needed for the integrated development of the Growth Pole (GP), regardless of the financing source (EU or state budget): e.g., research projects, climate change projects, energy projects, etc.

Discussions with representatives of local authorities and Regional Development Agencies revealed that most of the projects financed by other OP are not included in the IUDPs and only projects with little impact at the regional level were financed, partly due to "first come, first served" selection model used by the Regional Operational Program (except for Axis 1.1 for GPs and Urban 
Development Poles). Moreover, projects financed under the IUDP were suggested by the municipalities' representatives, often without proper consultations with relevant actors.

\subsection{ITI and Growth Poles}

In principle, GPs could fulfil the main criteria to implement ITI - i.e., an integrated strategy for a designated territory, with a clear package of actions with the involvement of a broad range of local partners. Taking into account the manifold problems that have appeared in Romania during the 2007-2013 implementation period, other criteria should be developed in selecting ITI areas: the record of contracting rates and absorption rates are two potential options. Consequently, a successful ITI may follow the logical scheme presented in Figure 2.

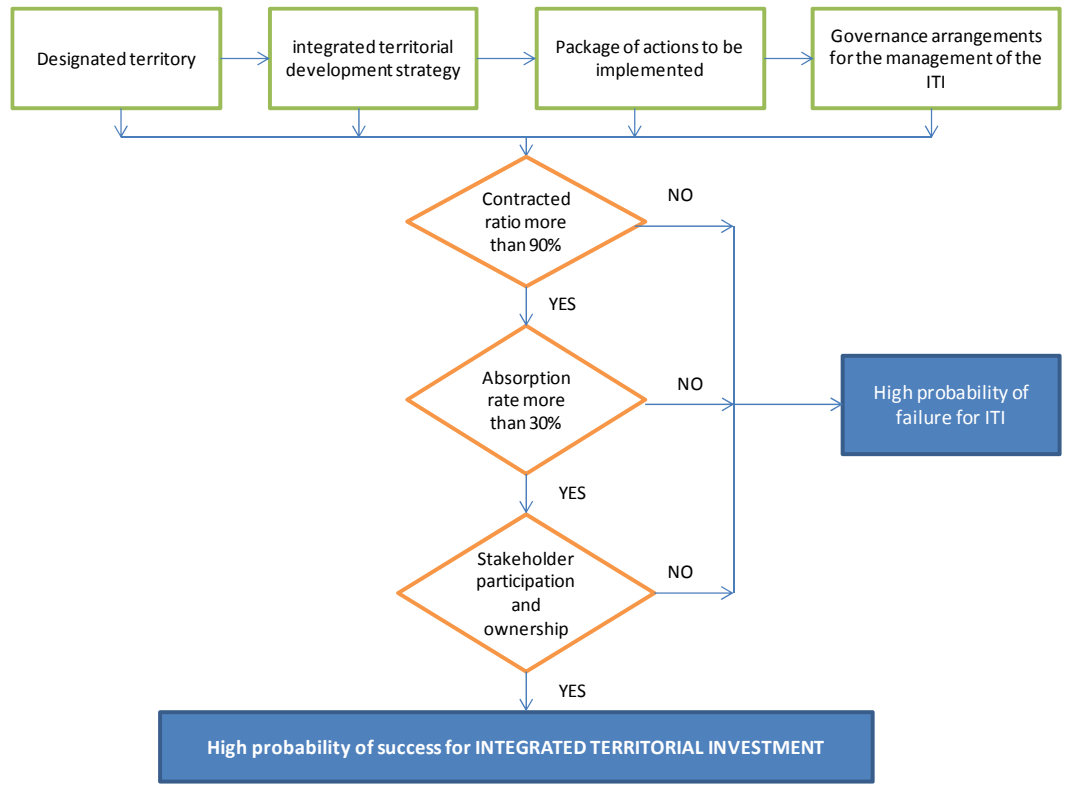

Figure 2: ITI logical scheme.

Main requirements included in the official documents are considered compulsory, but in addition important implementation indices should be included to confer additional credibility:

Contracted ratio of the GP represents the ratio between the total contracted value of projects and the initial allocated value for the previous programming period (e.g., 2007-2013). According to Regional Development Agencies where GPs are located, in April 2014, most of the GPs had exceeded the contracted values as presented in Table 2 . 
Table 2: Contracted ratio for the GPs.

\begin{tabular}{|l|l|}
\hline Growth Pole & Contracted ratio (\%) \\
\hline Brasov & 111 \\
\hline Cluj Napoca & 123,56 \\
\hline Constanta & 83,47 \\
\hline Craiova & 105,95 \\
\hline Iasi & 100,6 \\
\hline Ploiesti & 111,44 \\
\hline Timisoara & 105,18 \\
\hline
\end{tabular}

The logical scheme proposes a contracted ratio limit of $90 \%$, consequently most of GPs would fulfil this condition.

The absorption rate represents the ratio between the reimbursed value and the total allocated value for each GP. The threshold is proposed to be fixed at $30 \%$, close to the current average absorption rate for Romania, which is still the worst performer in the EU in this regard, as of July 2014).

Table 3: Absorption rates for the GPs.

\begin{tabular}{|l|c|c|c|}
\hline Growth Pole & $\begin{array}{c}\text { Total allocated } \\
\text { value (MEUR) }\end{array}$ & $\begin{array}{c}\text { Reimbursed value until } \\
\text { May, 2014 (MEUR) }\end{array}$ & $\begin{array}{c}\text { Absorption rate } \\
\text { (\%, May 2014) }\end{array}$ \\
\hline Brasov & 74.3 & 13.8 & 18.6 \\
\hline Cluj Napoca & 82.4 & 30.3 & 36.77 \\
\hline Constanta & 90.32 & 15.2 & 16.8 \\
\hline Craiova & 95.5 & 26.1 & 27.4 \\
\hline Iasi & 111.25 & 36.3 & 32.6 \\
\hline Ploiesti & 97 & 10.661 & 11 \\
\hline Timisoara & 74.14 & 12.8 & 17.3 \\
\hline
\end{tabular}

The absorption rate presented in Table 3 for Romanian GPs was calculated using public data available on the web sites www.mdrap.ro, www.inforegio.ro.

Since all seven Romanian GPs were involved in URBACT projects: Ploiesti (Creative clusters), Brasov (LINKS project), Craiova (ENTER.HUB), Constanta (URBAMECO project), Iasi (ReBLOCK project), Timisoara (MILE project), and Cluj (UNIC project) they have previous experience of multi-stakeholder Local Support Groups - LSGs.

Consequently, all the three steps may be successful in implementing ITI for all the GPs.

Nevertheless, in order to maximize the impact of the actions included in ITI, it is important to prioritize those that may have a significant impact in the designated area since resources, both financial and human, are limited. As a best practice, stakeholders involved in an ITI should to elaborate an impact matrix, including a detailed assessment of all types of effects (environmental, health, social impacts, etc.) of various actions. When evaluating the impact, both the implementation and operation (post-implementation) phases of the project should be considered. More specifically, impacts are defined as identifiable 
changes that demonstrate the extent to which actions included in the ITI have an effect on the target group/beneficiaries. These changes can take place during the project's lifetime (specific impacts) and/or beyond its lifetime (strategic impacts). Performance indicators should be used to determine the success of the action in reaching its objectives.

Table 4 presents a basic impact assessment framework that can potentially be used for selecting projects under an ITI. Within each box, a number from 1 to 10 may be assigned to indicate the magnitude of impact; 10 represents the greatest magnitude and 1 the least. The beneficial impacts may be identified with a "+" and detrimental impacts with a “-” sign.

For instance, an infrastructure project may have a mostly negative specific impact on the environment, a positive impact on the social level, negative on the energy level during the action's implementation, etc. However, a research project may have a positive impact on energy, health level, etc. The strategic impact may be positive for both types of actions.

The impact list in the matrix is certainly not exhaustive and it may be completed depending on the type of actions proposed. There is such wide variety of actions that no scheme of impact assessment can be universally applicable. However, the greatest need is not for a single and universally applicable assessment method, but rather for a simple way of summarizing which impacts are considered of greatest relevance by the people conducting the assessment.

Different assessors will seldom come to identical conclusions, but it would be useful to know the basis for the difference. The advantage of the matrix is in its use as a checklist or reminder of the full range of impacts. The matrix and suggested method of use are illustrative and can be subject to improvement, expansion, and adjustment. At the same time, the capacity of potential beneficiaries (i.e., local administrations) should be taken into account - larger cities (e.g., GPs) may afford more complex analyses and may measure indicators more precisely, while smaller urban centers may choose a more basic list. The key point is to encourage local beneficiaries of ITI projects to conduct such exercises and engage in a project selection/prioritization process that is as objective and as rigorous as possible.

\section{Case study - ITI Bucharest}

The Bucharest case study was selected to illustrate the impact assessment matrix on climate change for an ITI using indicators/parameters attainable through the Earth Observations methods. Bucharest is not defined by legislation as GP even if it is the capital of Romania, the largest city in the country and of course an attraction pole. Nevertheless it has its own strategy [8] that can be used as future foundation for ITI, since the IUDP of the different sectors are not integrated at central level. At the same time Bucharest will benefit from the results of the "Urban Climate Study of Bucharest, Romania" project, developed by Technical University of Civil Engineering Bucharest, in partnership with University of 


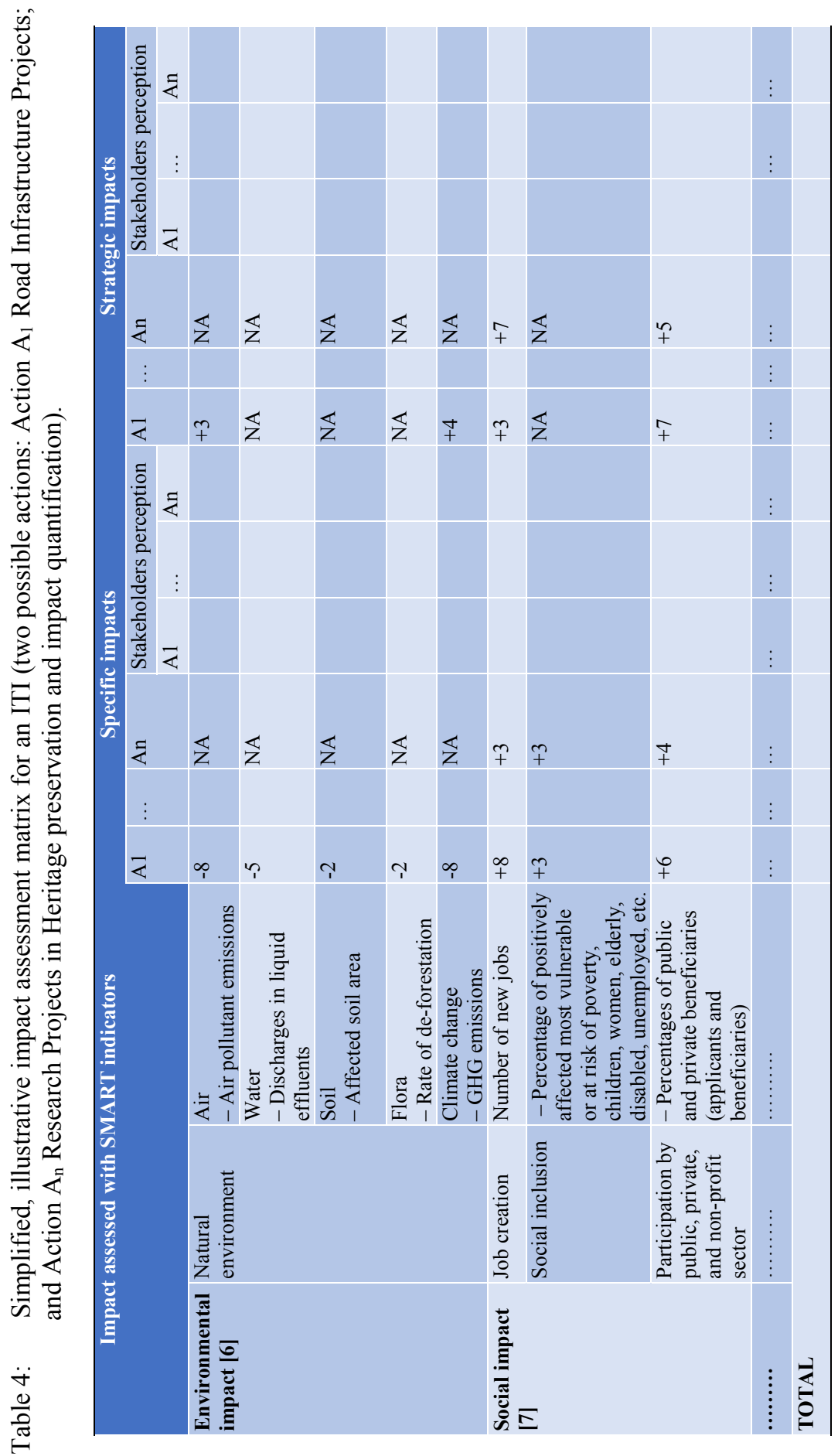




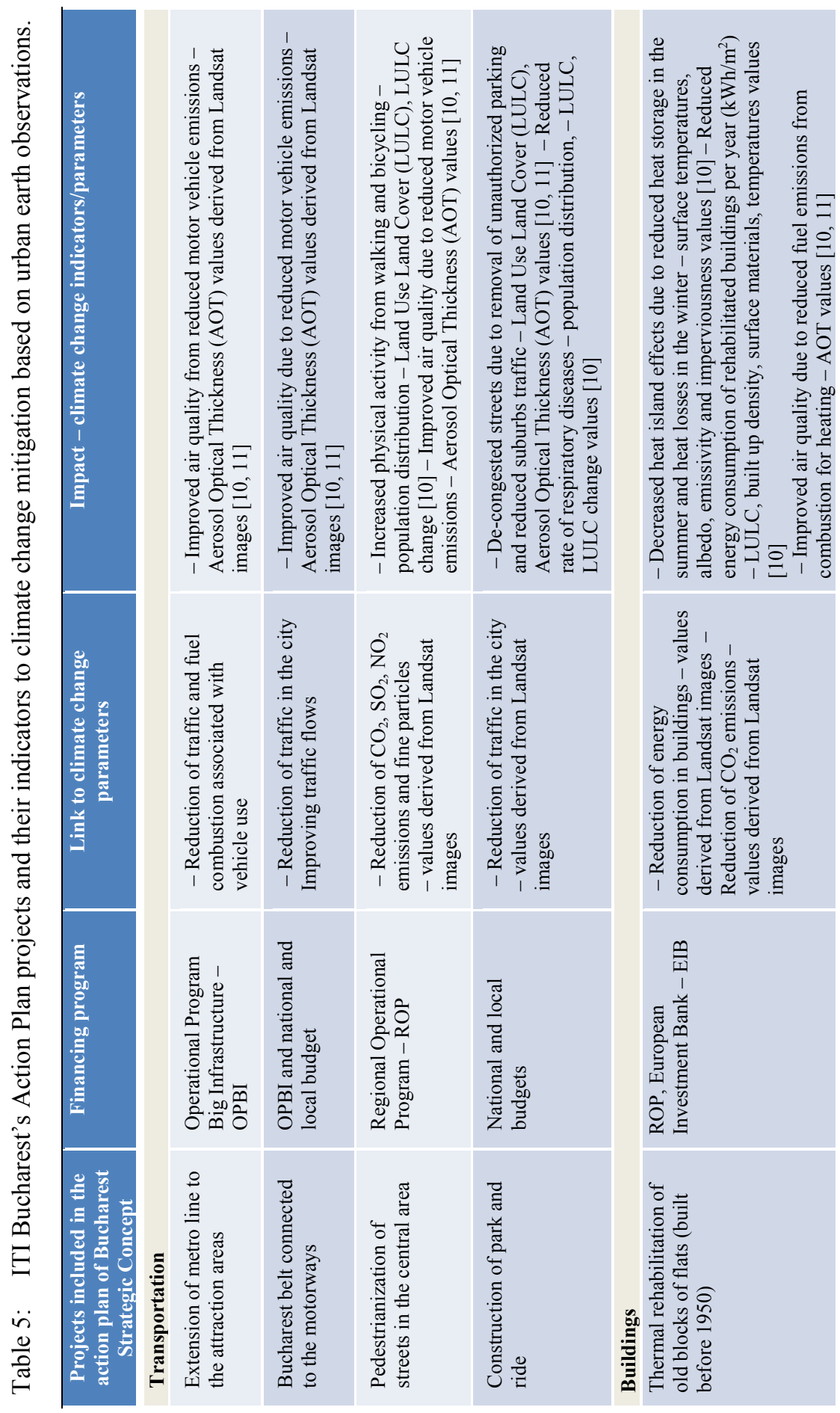

WIT Transactions on The Built Environment, Vol 168, (C) 2015 WIT Press www.witpress.com, ISSN 1743-3509 (on-line) 


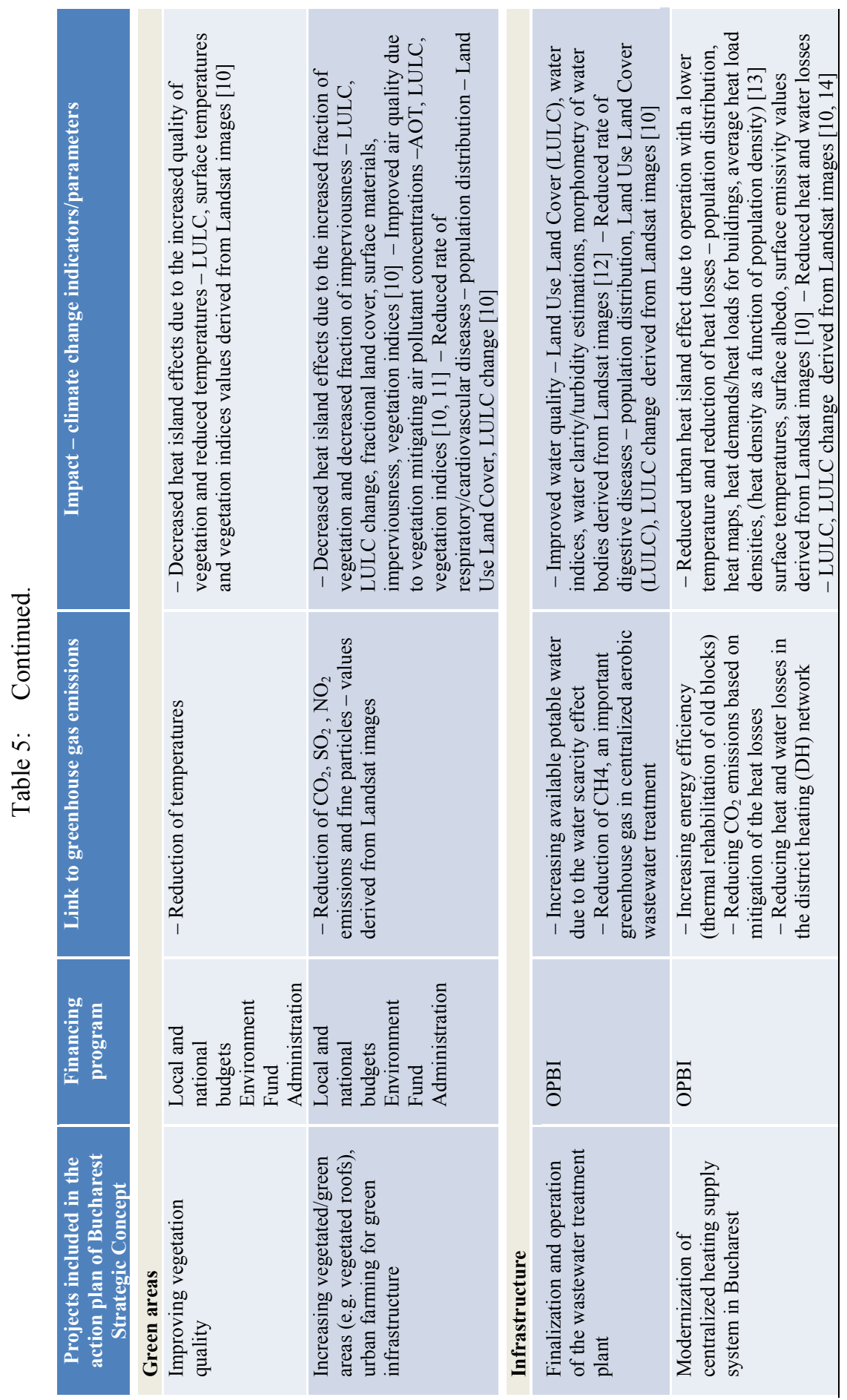

WIT Transactions on The Built Environment, Vol 168, (C) 2015 WIT Press www.witpress.com, ISSN 1743-3509 (on-line) 
Basel, under the framework of the Romanian-Swiss Research Programme 2011-2016 (RSRP 2011). One of the main results of this project is to propose certain urban climate strategies firstly for Bucharest, followed-up by its extension at the national level. The urban climate strategies will account for the reduction of the urban heat island effect, air pollution and heat stress for the improvement of the human comfort. Some of the Earth Observations indicators that will be itemized bellow are included in the preliminary results of this study in Table 5, characteristic for the subject of climate and developed in correlation with temperature variations and greenhouse emissions $[9,10]$, parameters such as the Land Use Land Cover classes and changes, vegetation and water indices.

\section{Conclusions, proposals and recommendations at local level}

Despite current policy options and limitations, ITI could still be adopted (informally) at the level of local beneficiaries. Specifically, even if the use of ITI is optional, in Romania it could be deployed for the purpose of integrated urban development, in accordance with Article 7 of the ERDF Regulation. Highperforming GPs (in terms of contracting and absorption) may be considered as prime candidates for ITI implementation in the 2014-2020 programming period.

To be more efficient in the prioritization of projects within an ITI, a dedicated matrix, such as the one presented in this article, may be developed in the attempt of quantifying the impact of proposed actions in the designated area. The broader aim is to adopt a more objective, rigorous, and impactful approach to selecting projects with a high value-add to Romania's sustainable and inclusive development. At the same time ITIs including improvement of transportation, energy efficiency of buildings, and inclusion of new and complex green structures can provide opportunities in mitigating climate change.

\section{References}

[1] Draft guidance fiche for desk officers - Integrated Territorial Investment (ITI); European Commission, version 3, 28 ${ }^{\text {th }}$ January 2014, http://ec.europa.eu/regional_policy/sources/docgener/informat/2014/guidan ce iti.pdf

[2] Soto, P., Houk, M., Ramsden, P. \& Tosics., I., Integrated Territorial Investments. A powerful tool for innovation and change in European cities, 2012, http://ldnet.eu/tiki-download_wiki attachment. php?attId=34

[3] Identification of project selection models for the Regional Operational Programme 2014-2020; World Bank.

[4] Romanian Partnership Agreement for the 2014-2020 Programming Period; Ministry of European Funds - official version, March 2014.

[5] Tosics, I., New tools for integrated urban development: ITI and CLLD in national context, EUKN Policy Lab Romania "Integrated approach in urban planning and development", Bucharest, 11 October 2013.

[6] International Atomic Energy Agency Vienna - Energy Indicators for Sustainable Development: Guidelines and Methodologies, 2005. 
[7] Burdge R. J. \& Vanclay F. Social impact assessment: a contribution to the state of the art series, Impact Assessment, 14(1), pp. 59-86, 1996.

[8] Conceptul strategic Bucuresti 2035, www.csb2035.ro

[9] Younger, M., Morrow-Almeida, H. R., Vindigni, S. M., \& Dannenberg, A. L., The built environment, climate change, and health: opportunities for cobenefits. American Journal of Preventive Medicine, 35(5), pp. 517-526, 2008.

[10] Chrysoulakis, N., Feigenwinter, C., Triantakonstantis, D., Penyevskiy, I., Tal, A., Parlow, E., Marconcini, M., A Conceptual List of Indicators for Urban Planning and Management Based on Earth Observation. ISPRS International Journal of Geo-Information 3(3), pp. 980-1002, 2014.

[11] Kleanthous, S., Savvides, S., Christofides, I., Hadjimitsis, D. G., Themistocleous, K., Achilleos, C., \& Kubat, M., Particulate monitoring; modeling; and management: natural sources, long-range transport; and emission control options: a case study of Cyprus. Proc. SPIE 8795, First International Conference on Remote Sensing and Geoinformation of the Environment, International Society for Optics and Photonics, 2013.

[12] Zeilhofer, P., Lima, E. B., \& Lima, G. A., Spatial Patterns of Water Quality in the Cuiabá River Basin, Central Brazil. Environmental Monitoring and Assessment, 123(1-3), pp. 41-62, 2006.

[13] Finney, K. N., Sharifi, V. N., Swithenbank, J., Nolan, A., White, S. \& Ogden, S., Developments to an existing city-wide district energy network, Part I: Identification of potential expansions using heat mapping. Energy Conversion and Management, 62, pp. 165-175, 2012.

[14] Ayala, T. G., Okumura, M. \& Kim, J., Land use change detection by satellite images and its application on pipe lines age and water loss estimation. The Fourth Asian Seminar in Regional Science. Seoul, 2014 Online. http://strep.main.jp/uploads/mokmrp3/aok1408seoul.pdf 